\title{
Population studies of causative agent of wheat yellow rust in the Northwest Russia
}

\author{
Ekaterina L. Shaydayuk ${ }^{1, *}$, Elena I. Gultyaeva ${ }^{1}$ \\ ${ }^{1}$ All Russian Institute of Plant Protection, Laboratory of Mycology and Phytopathology, 196608 \\ Saint Petersburg, Russia
}

\begin{abstract}
Wheat yellow rust (causative agent Puccinia striiformis West.) is a widespread disease of common wheat in the North-West Russia. A comparative analysis of $P$. striiformis populations, collected in the Leningrad region in 2019 on wheat and triticale, by virulence and racial composition was carried out for the first time. Virulence and racial composition of $P$. striiformis were studied using international and European sets of differentiating varieties and isogenic lines of "Avocet" with $20 \mathrm{Yr}$ genes. A total of 55 single-pustule isolates of $P$. striiformis were studied, including 31 from common wheat, 10 from durum wheat and 14 from triticale. Using differentiating varieties, 2 races $(111 \mathrm{E} 247,110 \mathrm{E} 247)$ were identified among isolates from common wheat, 3 races from durum wheat (111E213, 111E231, 111E247), and 5 races from triticale (111E247, 78E209, 79E209, 111E231, 78E215). Using "Avocet" isogenic $Y r$ lines, all isolates were avirulent to lines with the $\operatorname{Yr} 5, \operatorname{Yr} 10, \operatorname{Yr} 11, \operatorname{Yr} 12, \operatorname{Yr} 15, \operatorname{Yr} 24$, $\operatorname{Yr} 26$ genes and virulent to $\operatorname{Yr} 6, \operatorname{Yr} 7, \operatorname{Yr} 8, \operatorname{Yr} 9, \operatorname{Yr} 18, \operatorname{YrSp}, \operatorname{YrJr}(18), \operatorname{YrAS}$ genes. Isolates virulent to $\mathrm{Yr} 17$ were revealed on triticale; avirulent to $\mathrm{YrSk}$ (27) - on durum wheat. and avirulent to $Y r A R$ - on triticale. Highly effective $\mathrm{Yr}$ genes can be recommended for wheat resistance breeding to to yellow rust.
\end{abstract}

\section{Introduction}

Yellow rust is a widespread disease of common wheat affected leaves, leaf sheaths, spikelet bracts and rarely stems. Lemon-yellow uredinia-pustules appear on them, they are arranged in longitudinal rows. The main difference of the yellow rust pathogen from other wheat rust species is the development at low temperatures $\left(2-15^{\circ} \mathrm{C}\right)$ at high humidity [1].

The significance of yellow rust began to increase since the 1990s. Its epyphitoties have been repeatedly noted in Western Europe, Australia, North Africa, Central and East Asia [15]. In Russia, the disease has a regional importance in the North Caucasus [6-7]. The epiphytotic development of yellow rust was observed there in 1996-1997 [8] and in 2001 [9]. In 2003-2018 disease severity ranged from 0 to $20 \%$.

Increased sporadic development of yellow rust is also noted in the North-West of Russia. The pathogen is annually observed on wheat and triticale varieties studied at the State cultivar

\footnotetext{
*Corresponding author: eshaydayuk@bk.ru
} 
plots in the Leningrad region, and in some years the disease was widespread in experimental and commertial fields [10-11].

A scientifically based strategy of wheat genetic protection from diseases involves the development and spatial distribution of varieties with different genetic basis. The implementation of this is impossible without the study of virulence and racial composition of pathogen populations. The virulence analysis of $P$. striiformis populations untill now been carried out only in the North Caucasus region of Russia [12-13]. The purpose of these studies was to study the virulence and racial composition of $P$. striiformis populations in the Northwest Russia.

\section{Materials and methods}

Population samples of P. striiformis were collected in 2019 at two locations: on the experimental field of the N.I. Vavilov Research Institute of Plant Industry (St. Petersburg, Pushkin), where the epiphytotic development of this disease was observed; and at the Gatchinsky State variety test plot (Leningrad region), where a moderate severity of crops was observed. In the experimental field, the infectious material was collected from common spring (Triticum aestivum) and durum wheat (T. durum) varieties and triticale, and at the State test plot - from triticale.

For multiplication of pathogen populations Freshly collected wheat leaves with urediniapustules were used. In the laboratory, they were cut into segments of 5-8 cm and laid out in Petri dishes. The ends of the leaves were covered with cotton moistened with a solution of benzimidazole $(0.004 \%)$ and placed in a refrigerator (temperature $3-5^{\circ} \mathrm{C}$ ) for $2-4$ days [14]. This technique allowed to stimulate the fresh sporulation of the pathogen. Spores were collected by a vacuum pump with a special mini nozzle. 10-12-day old plants of a universally susceptible wheat variety (Michigan Amber) were inoculated with an aqueous spore suspension (with the addition of Tween 80 detergent). After inoculation the pots were covered with scaffolds with polyethylene insulators, transferred to the climate chamber "Versatile Environmental Test Chamber MLR-352H" (SANYO ElectricCo., Ltd., Japan) and kept in the dark at a temperature of $10^{\circ} \mathrm{C}$ for $14-16$ hours. Next, the scaffolds were removed, and the plants were incubated for six hours at a temperature of $20-22^{\circ} \mathrm{C}$, intense light $(25000$ 30000 lux) and a humidity of $100 \%$. After that, the following conditions were established: 16 hours - temperature of $16^{\circ} \mathrm{C}$, humidity $70 \%$, illumination $15000-20000$ lux; 8 hours without lighting, temperature of $10^{\circ} \mathrm{C}$, humidity $70 \%$. The first symptoms of the disease (pustules) were observed after 14-18 days. Spore collection was carried out on 18-20 days after inoculation. In order to obtain single-pustule isolates, leaves with separately located pustules were used, which were propagated according to the method described above. To prevent contamination beetwin isolates, the plants were covered with a scaffold with a special perforated polyethylene throughout the entire period.

The racial composition of $P$. striiformis was studied using international and European sets of differentiating varieties. The international set included seven wheat varieties: Chinese 166 $(Y r 1)$, Lee $(Y r 7, Y r 22, Y r 23)$, Heines Kolben (Yro), Vilmorin 23 (Yr3a), Moro (Yr10), Strubes Dickkopf, Suwon 92/Omar); the European set included eight varieties: Hybrid 46 ( $\mathrm{Yr} 3 \mathrm{~b}$, $Y r 4 b)$, Reichersberg 42 (Yr7), Heines Peko, Nord Desprez (Yr3a), Compair (Yr8), Carstens $\mathrm{V}$, Spaldings Prolific, Heines VII $(Y r 2)$. To study the efficiency of $Y r$ genes and the characteristics of populations by virulence, "Avocet" isogenic lines with the $\operatorname{Yr} 1, \operatorname{Yr} 5, \operatorname{Yr} 6$, Yr7, Yr8, Yr9, Yr10, Yr11, Yr12, Yr15, Yr17, Yr18, Yr24, Yr26, YrSk(27), YrAR, YrSp genes were used. The seeds of differentiating varieties were kindly provided by A.S. Rsaliev (Research Institute for Biological Safety Problems, Kazakhstan, Jambyl region). 
Decimal abbreviations were used to indicate races that were identified using the international and European sets. Its basis is a binary system for identifying types of infection (a resistant type of reaction (R) is designated as 0 , susceptible (S) as 1) and a decimal system for identifying each variety (first differentiator is $2^{0}$, the second is $2^{1}$, the third is $2^{2}$, etc.). According to this system, if only the first variety-differentiator (20) was infected, then this is race 1 , if the first and the second $\left(2^{0}+2^{1}\right)$, then this will be the race 3 , i.e. the total sum is the race number. Due to the fact that we used two sets of differentiating varieties, the international and European, when naming the race, they first indicated the number according to the international set, then the number according to the European set with the prefix "E" (for example, 1E3).

14-16-day old plants of differentiating varieties and $Y r$ lines were used in the virulence analysis (second leaf stage). Inoculation and subsequent incubation were performed according to the abovementioned method. Each single-pustule isolate was tested on differentiators set twice; in case of mismatch of the reaction, the experiment was repeated until a stable result was obtained.

The reaction types of differentiators was evaluated on a G. Gassner and W. Straib scale (1932), where a score of 0 ; - high resistance (no pustules or necrotic spots), score 1 resistance (a few very small pustules with necrosis), score 2 - moderate resistance (formation of pustules is weak, small pustules with necrosis), score 3 - moderate susceptibility (medium and large pustules with necrosis and chlorosis), score 4 - high susceptibility (large pustules with chlorosis) [15]. Plants with scores of 0-2 were classified as resistant, with scores of 3-4 - as susceptible.

\section{Results and discussion}

In total, 55 single-postule isolates of $P$. striiformis were studied, including 31 isolated from common wheat varieties, 10 from durum wheat and 14 from triticale varieties.

Using differentiating varieties among isolates from common wheat, 2 races (111E247, $110 \mathrm{E} 247)$ were identified, 3 races from durum wheat $(111 \mathrm{E} 213,111 \mathrm{E} 231,111 \mathrm{E} 247)$, and 5 races from triticale (111E247, 78E209, 79E209, 111E231, 78E215) (Table 1). All identified races were avirulent to the varieties Moro (Yr10), Nord Desprez (Yr3a, Yr4a). The race $111 \mathrm{E} 247$ was revealed in all subpopulations. Its frequency was higher on common wheat $(88 \%)$ than on durum wheat and triticale ( $20 \%$ and $29 \%$, respectively). This race is virulent to all differentiating varieties, with the exception of Moro and Nord Desprez. The race 111E231 was observed on $r$ durum wheat and triticale. It differed from 111E247 by avirulence to the variety Chinese 166. All other identified races were original and were noted on one of the host species. A distinctive difference of races on triticale and T. durum from races on common wheat was the avirulence to differentiating varieties Strubes Dickkopf, Heines Peko, Compair, and Carstens V. The diversity of racial composition was higher in the subpopulation from triticale than from the other two host species. 
Table 1. Characterization of Puccinia striiformis populations from common and durum wheat and triticale for virulence and racial composition in Northwest Russia in 2019

\begin{tabular}{|c|c|c|c|}
\hline \multirow[t]{2}{*}{ Parameter } & \multicolumn{3}{|c|}{ P. striiformis host species } \\
\hline & $\begin{array}{c}T . \\
\text { aestivum }\end{array}$ & T. durum & $\begin{array}{c}\text { Tritical } \\
\mathrm{e}\end{array}$ \\
\hline Number of isolates & 31 & 10 & 14 \\
\hline Number of races ${ }^{a}$ & 2 & 3 & 1 \\
\hline \multicolumn{4}{|l|}{ Race frequency $(\%)$ : } \\
\hline $111 \mathrm{E} 247$ & 88 & 20 & 29 \\
\hline $110 \mathrm{E} 247$ & 12 & 0 & 0 \\
\hline $111 \mathrm{E} 213$ & 0 & 60 & 0 \\
\hline $111 \mathrm{E} 231$ & 0 & 20 & 50 \\
\hline 78E209 & 0 & 0 & 7 \\
\hline 79E209 & 0 & 0 & 7 \\
\hline $78 \mathrm{E} 215$ & 0 & 0 & 7 \\
\hline \multicolumn{4}{|c|}{ Virulence frequency on "Avocet" lines with $Y r$ genes $(\%)$ : } \\
\hline$Y r: 5,10,11,12,15,24,26$ & 0 & 0 & 0 \\
\hline Yrl & 88 & 100 & 72 \\
\hline $\operatorname{Yr} 17$ & 0 & 0 & 14 \\
\hline$Y r S p$ & 100 & 100 & 86 \\
\hline $\operatorname{YrSk}(27)$ & 100 & 80 & 100 \\
\hline $\operatorname{YrAR}$ & 100 & 100 & 86 \\
\hline$Y r: 6,7,8,9,18, \mathrm{Sp}, \operatorname{Jr}(18), \mathrm{AvS}$ & 100 & 100 & 100 \\
\hline average number of virulence alleles ${ }^{b}$ & 12.1 & 12 & 11.8 \\
\hline
\end{tabular}

Note: races were identified ${ }^{a}$ using the international and European sets of differentiating varieties; ${ }^{b}$ using isogenic lines of "Avocet" with $20 \mathrm{Yr}$ genes

Using "Avocet" isogenic $Y r$ lines (Table 1), all isolates were avirulent to lines with the $\operatorname{Yr} 5, \operatorname{Yr} 10, \operatorname{Yr} 11, \operatorname{Yr12}, \operatorname{Yr} 15, \operatorname{Yr} 24, \operatorname{Yr} 26$ genes, and virulent to the carriers of the $\operatorname{Yr} 6, \operatorname{Yr} 7$, $\operatorname{Yr} 8, \operatorname{Yr} 9, \operatorname{Yr} 18, \operatorname{YrSp}, \operatorname{YrJp}(18), \operatorname{YrAS}$ genes. Isolates virulent to $\operatorname{Yr} 17$ were revealed on triticale; avirulent to $\operatorname{YrSk}(27)$ on durum wheat, and avirulrnt to $Y r A R$ on triticale.

As a result of a combined analysis of the northwest populations of the yellow rust pathogen on common and durum wheat and triticale, their difference in virulence was revealed, which indicates the influence of the genomes of these crops on selection in the pathogen population. Common wheat and triticale are the main crops cultivated in the Northwest Russia. Durum wheat is not grown in that region. However, in other regions, where these crops are grown, immunological studies should take this fact into account and use inoculuml, which is specific to each crop.

The $\operatorname{Yr} 9$ and $\operatorname{Yr} 18$ genes are widespread in Russian common wheat varieties. The $\operatorname{Yr} 9$ gene localized in the wheat-rye translocation 1BL.1RS, which carries the complex of resistance genes $\operatorname{Lr} 26 / \mathrm{Sr} 31 / \mathrm{Pm} 8$, and belongs to the group of genes that provide race-specific resistance. It is likely that long-term cultivation of varieties with this translocation in Russia predetermined a loss in the efficiency of the $\operatorname{Yr} 9$ gene, as is observed for the wheat leaf rust resistant gene Lr26and powdery mildew resistant gene Pm8. The $Y r 18 / \operatorname{Lr} 34 / \mathrm{Sr} 57 / \mathrm{Pm} 38$ genes cluster, which determine the quantitative resistance to leaf and stem rusts and powdery mildew in the adult plant stage [16]. Varieties with the $\operatorname{Yr} 18$ gene have also been grown widely in Russia for more than half a century, which predetermined the loss of its effectiveness. Most of the effective genes identified in these studies (Yr5, $\operatorname{Yr10}, \operatorname{Yr} 11, \operatorname{Yr} 12$, $\operatorname{Yr} 15, Y r 24, Y r 26$ ) also show their effectiveness in the North Caucasus [13] and in some other countries [17]. 


\section{Conclusion}

Analysis of virulence and racial composition of the wheat yellow rust pathogen population in the Northwest Russia was carried out for the first time. The influence of host plants with different ploidy and genomes $(2 \mathrm{n}=42$ T. aestivum (BBAADD), $2 \mathrm{n}=28$ T. durum (BBAA), $2 \mathrm{n}=42$ Triticale (BBAARR)) on the selection of the pathogen population was reveal. Highly effective $\mathrm{Yr}$ genes can be recommended for resistance breeding to yellow rust.

The current research was supported by RSF grant No. 19-76-30005.

\section{References}

1. W. Chen, C. Wellings, X. Chen, Z. Kang, T. Liu, Mol. Plant Pathol. 15, 433 (2014)

2. M. Koyshibaev, Mycol. Phytopathol. 36, 83 (2002)

3. M. S. Hovmøller, A. F. Justesen, J. K. M. Brown, Plant Pathology 51, 24 (2002). DOI: 10.1046/j.1365-3059.2002.00652.x

4. X. M. Chen, Canadian Journal of Plant Pathology 27, 314 (2005). DOI: $10.1080 / 07060660509507230$

5. C. R. Wellings, Euphytica 179, 129 (2011). DOI: 10.1007/s10681-011-0360-y

6. S. S. Sanin, L. N. Nazarova, Plant Protection and Quarantine 2, 69 (2010)

7. G. V. Volkova, L. N. Shulyakovskaya, O. A. Kudinova, I. P. Matveeva, Plant Protection and Quarantine 4, 22 (2018)

8. V. T. Goncharov, V. P. Chuprina, Plant Protection and Quarantine 4, 28 (1999)

9. Yu. I. Berdysh, Monitoring fitosanitarnogo sostoyaniya $i$ nauchnoe obosnovanie zashchity ozimoj pshenicy ot vrednyh organizmov na chernozemah Zapadnogo Predkavkaz'ya [Monitoring the phytosanitary condition and the scientific basis for the protection of winter wheat from harmful organisms on the black earth of the Western Ciscaucasia] (Krasnodar, 2002)

10. E. I. Gultyaeva, M. M. Levitin, N. F. Semenyakina, N. V. Nikiforova, N. I. Savelyeva, Plant Protection and Quarantine 6, 15 (2007)

11. E. I. Gultyaeva, E. L. Shaydayuk, N. P. Shipilova, M. M. Levitin, I. V. Maslova, M. P. Vusatyuk, O. A. Kolesnikova, Plant Protection and Quarantine 4, 19 (2018)

12. A. N. Matvienko, Selektsiya i semenovodstvo 5, 36 (1973)

13. G. V. Volkova, I. P. Matveeva, O. A. Kudinova, Mycology and Phytopathology 54, 33 (2020)

14. L. A. Mikhailova, E. I. Gultyaeva, N. V. Mironenko, Methods for studying the structure of populations of the leaf rust causative agent (VIZR, St. Petersburg, 1998)

15. G. Gassner, W. Straib, Arb. Biol. Reichsanst. Land-Forst-wirtsch Berlin-Dahlem. 16, 609 (1932)

16. E. E. Radchenko, R. A. Abdullaev, I. N. Anisimova, Russian Journal of Genetics: Applied Research 18, 59 (2020). DOI: 10.17816/ecogen14530

17. M. S. Hovmøller, J. Rodriguez-Algaba, T. Thach, A. F. Justesen, J. G. Hansen, Global Rust Reference Center (2017) 